\title{
Confronting the Problems of Colonialism, Ethnicity and the Nigerian Legal System: The Need for a Paradigm Shift
}

\author{
Melvin Leslie Mbao \\ Executive Dean, Faculty of Law, North West University, Mafikeng Campus, South Africa \\ Email:Melvin.Mbao@nwu.ac.za \\ Olusegun Michael Osinibi
}

Lecturer, Department of Private Law, Faculty of Law, Olabisi Onabanjo University, Ago-Iwoye, Ogun State, Nigeria

Email: osinibimike@yahoo.com

\section{Doi:10.5901/mjss.2014.v5n27p168}

\begin{abstract}
Nigeria secured independence from Britain over fifty years ago but prevailing socio-political turmoil and economic woes in Nigeria are attributed to colonialism and the forced amalgamation of the diverse ethnic units constituting Nigeria. The need to redress the long-standing marginalization of certain units due to colonialism accounts for the entrenchment of the Federal Character principle in the Nigerian Constitution. However, ethnic discontent and intolerance still pervades Nigeria while the oil curse has led to Nigeria's categorization as a rentier state. This paper argues that notwithstanding the effects of colonialism, Nigeria, with its vast endowment of human and natural resources can overcome the contemporary challenges of intense ethnic conflicts and other socio-economic problems if the Government eschews corruption. The paper also examines the relics of colonial law in Nigerian statutes and legal practice and contends that time-worn British laws in Nigerian statutes need to be jettisoned to accommodate present realities.
\end{abstract}

Keywords: Colonialism, Nigeria, Ethnic Conflicts, Rentier State, Federal Character Principle

\section{Introduction}

The geographical entity now known as Nigeria, like many other countries the world over, tasted the bitter pills of colonialism administered by the imperial muscles of Great Britain. The Nigerian entity, an artificial creation made up of people of diverse ethnicity, cultures, languages, norms and expectations was established in 1914 by the amalgamation of the Northern and Southern Protectorates (Lalude \& Omitola, 2001). Although Nigeria attained independence on October $1^{\text {st }} 1960$, the negative legacy of colonialism still endures till today. Fundamental problems in the Nigerian polity are attributed to colonialism and the forced amalgamation which created the Nigerian entity (Abdulrahman, 2004; Adefulu, 2001). Apart from some semblance of inferiority complex foisted on Nigerians due to colonialism, relics of colonialism still pervade the Nigerian Legal System in the form of Statutory Regulations and Procedural laws imported from Great Britain. However the most poignant of the colonial legacies which threatens the corporate existence of Nigeria is the enduring mutual distrust and ethno-phobia created among the various ethnic groups in Nigeria.

Nigeria as one of the major exporters of crude oil in the world is ironically one of the world's poorest countries, ravaged by massive corruption (World Bank, 2013a), abject poverty of citizens and most worrisome, ethnic tensions and xenophobic intolerance (Uhunmwuangho \& Epelle, 2011; Aleyomi, 2012; Ensign, 2012). This raises the question whether a solution to the prevalent ethnic crisis can be found or whether the blame should be placed at the feet of colonialism with hands raised in despair amidst strident calls for a break-up of the component units of Nigeria, thus replicating the occurrence in countries such as Yugoslavia and Czechoslovakia(Bunce, n.d.; Engelberg,1993). This paper is divided into five parts. The first part examines the impact of colonialism on Nigeria; the second part appraises the Federal Character principle in Nigeria's Constitution as a colonial legacy; the third part assess the strategies that can be adopted to wipe out the legacies of colonialism in Nigeria, the fourth part evaluates the status of Nigeria as a rentier state and the fifth part examines the influence of colonialism on Nigeria's legal system. 


\section{Effects of Colonialism on Nigeria}

A colony is a dependent territorial entity subject to the sovereignty of an independent country, but considered part of that country for purposes of relations with third countries (Black's Law Dictionary, 2009).

The geographical area now known as Nigeria became a British colony in the $19^{\text {th }}$ century and there is widespread consensus among scholars that the consequences of colonization on Nigeria have been unpalatable and a recipe for crisis (Dankofa,2008; Olaniyan \& Ala0,2003). Abdulrahman (2004,p.294) highlights some of the negative legacies of colonialism to include the "policy of separate development which engendered unequal and uneven distribution of economic and social development" in the different zones making up Nigeria. This is in addition to the "adoption of a dual urban policy particularly in Northern Nigeria and the creation of strangers' quarters" which fostered segregation (Abdulrahman, 2004, p. 294). In the economic sphere, the Nigerian economy was "incorporated into the world capitalist economy as an appendage" thereby subjecting the economy to the vagaries of the world capitalist economy(Abdulrahman, 2004, p. 294).

According to Eteng (2004, p.37), "Lugard's forced amalgamation of 1914, and subsequent British colonial policy of divide-and-rule, instigated inter-ethno-religious suspicion, residential segregation and antagonism among various communal groups" and this became aggravated due to the absence of any institution or mechanism to mediate between feuding and competing groups, or placate aggrieved groups (Apata, 1990). The negative perception of British colonial administration in Nigeria, personified by Lord Lugard's policies appears to be dissimilar to the perception held in central Africa where Lord Lugard's administrative policies, as set out in his book 'Dual mandate in Tropical Africa' are regarded as the shining example of British colonial policy in Africa till 1945 (Wills, 1966). His method is seen to have approved the economic development of colonial territories by their European communities whilst also preserving and developing African institutions. This culminated in the Passfield Memorandum of 1930 asserting the paramountcy of native interests (Wills, 1966). Lugard asserts that albeit British methods had not produced ideal results everywhere, British rule was fundamentally benign (Gerhart, 1997). He argued that the welfare and advancement of African peoples was the guiding principle of British rule and that Africans' discontent with British rule arose from the exposure of Africans to the British values of liberty (Gerhart, 1997). On the contrary, however, in the case of Nigeria, Azeez (2004, p.332) notes that the absence of socio-economic security under the colonial regime engendered a situation where indigenes resorted to ethnic affiliations for welfare support. It is further observed that the division of Nigeria into three regions for administrative purposes by the Richards Constitution of 1946 strengthened regional as opposed to national loyalty (Azeez, 2004, p.333).

Nigeria is made of numerous ethnic groups which include the Yorubas, Ibos, Hausas and many other groups numbering up to two hundred and fifty (World Fact Book, n.d.; Afonja, 2013). Ako-Nai(2004) argues that the colonial politics of divide-and-rule is mainly responsible for the propagation of ethnicity and ethnic rivalry in Nigeria as the British played the different ethnic groups against each other and thereby fostered ethnic differences, and at independence, there were no political institutions to protect the interests of the varying ethnic groups in Nigeria, including the minority groups. The ethnic rivalry and distrust engineered by colonialism was so intense that from independence till date, Nigeria's political discourse is strongly colored by regional affiliations and loyalty as well as class and ethnic cleavages. At present, the Action Congress of Nigeria (ACN) is the political party dominating the South-West States of Nigeria. The All Progressive Grand Alliance is a political party with its roots and stronghold in the Eastern States of Nigeria while the People's Democratic Party (PDP) which is the largest of the political parties and appears to have a nation-wide spread is mainly dominated by Northern Elites(Eames,1985; Azeez,2009; Okoye, Egboh \& Chukwuemeka,2012). The existence of only one party having a nation-wide spread is seen by Azeez (2009) as a stride into authoritarian one-party rule.

It must be noted that the regional affiliation of political parties is not a recent development, but rather, has become embedded in the Nigerian psyche since the colonial period. It has been suggested that the 1954 Macpherson Constitution in Nigeria precipitated regional politics when political parties were formed along ethnic lines. The National Council of Nigerian Citizens (NCNC) had its stronghold in the eastern region; the Northern People's Congress (NPC), as the name implies was the party for the northern region while the Action Congress belonged to the western region (Adebisi, 1999; Ako-Nai, 2004; Erhagbe, 2012). This situation precipitated what has been described as identity politics in Nigeria which persists till today (Iwara, 2004). The consequence of the colonially enforced formation of the Nigerian entity is best described by Eteng's compilation of several authors' uncomplimentary description of Nigeria such as "A notoriously precarious lumping together of peoples of separate identities"; "A mere collection of self-contained and mutually independent native states separated by great distance, differences in history, tradition, and ethnographical, racial, tribal, political, social and religious barriers. "The most artificial of any administrative units created in the course of British occupation of Africa (Eteng, 2004, p.39). 
Abdulrahman (2004, p.96) best sums up the impact of colonialism on ethnic unity in Nigeria thus:

In sum, Nigeria emerged out of the experience of colonial rule as a satellite or dependent neo-colonial economy, with a low level of social and political integration and therefore the absence of inter-ethnic trust, national society and leadership and uneven development between the constituent territorial units. More pertinently, the country inherited institutions and conditions which potentially made for the perpetuation and intensification of economic, social, political and geographic inequalities and a receptive disposition towards the use of force or violence as a means of securing one's group interests.

In view of the inequality and uneven development fostered by colonialism, steps have been taken after Nigeria's independence to remedy the situation. The most notable of these steps is the incorporation of the Federal Character principle into the 1979 and 1999 Constitutions of Nigeria, which is the fundamental law or grund-norm in Nigeria.

\section{The Federal Character Principle as a Colonial Legacy}

The Federal Character principle, also referred to as the quota system in Nigeria, has been likened to the affirmative action program adopted in the United States of America to redress the wrongs of racism and slavery. ${ }^{1}$ In the Nigerian context, the quota system was introduced to solve the problems of marginalization, disparity in socio-economic development and educational standards of different areas of Nigeria (Federal Character Commission, n.d.; Vincent, 2009; Uduchukwu, 2013). In other words, the Federal Character Principle has been described as a process of deliberate political engineering to address the problem of multi-ethnicity in Nigeria culminating from the forced union of different ethnicities by British colonial authority (Erhagbe, 2012,p.87; Kwarteng,2012; Ploch,2013).

Section 14 (3) of the Constitution of the Federal Republic of Nigeria (1999) states that:

The composition of the Government of the Federation or any of its agencies and the conduct of its affairs shall be carried out in such a manner as to reflect the federal character of Nigeria and the need to promote national unity, and also to command national loyalty, thereby ensuring that there shall be no predominance of persons from a few states or from a few ethnic or other sectional groups in that Government or in any of its agencies.

Section 14 (4) of the same Constitution (1999) stipulates that:

The composition of the Government of a state, a local government council, or any of the agencies of such Government or council, and the conduct of the affairs of the Government or council or such agencies shall be carried out in such manner as to recognize the diversity of people within its area of authority and the need to promote a sense of belonging and loyalty among all peoples of the Federation

Section 153 (1) (c) of the Constitution (1999) established the Federal Character Commission which commission has powers to, amongst other things, work out modalities for sharing posts and appointments in the public service. ${ }^{2}$ The spirit of the Federal Character principle is reflected in Section 147 (3) of the Constitution (1999) which stipulates that the appointment to the office of a Minister of the Government of the Federation shall be in conformity with the provisions of Section 14 (3) of the Constitution (1999), as reproduced above. The proviso to this subsection mandates the President to appoint at least one Minister from each state, who shall be an indigene of such state. Considering the fact that Nigeria has 36 states in addition to the Federal Capital Territory, it is submitted that this constitutional provision accounts for Nigeria's over-bloated federal cabinet and the concomitant escalation of expenses required to sustain such a cabinet(Oyeniya,2011).

A poignant colonial legacy found in the proviso to section 147 (3) of the Constitution (1999) is the stipulation that the Minister appointed from a particular state must be an indigene of the state. In other words, a person who was born and is domiciled in a particular state but with ancestral links to another state cannot aspire to hold a public office or be appointed as a Minister from such state due to the quota system (Nnochiri \& offide, 2012). This situation is akin to the policy of segregation encouraged by the British and it is submitted that national unity is not encouraged when a Nigerian

\footnotetext{
${ }^{1}$ Black's Law Dictionary (2009,p.68) defines Affirmative action as a set of actions designed to eliminate existing and continuing discrimination, to remedy lingering effects of past discrimination, and to create systems and procedures to prevent future discrimination.

${ }^{2}$ The powers of the Federal Character Commission are specifically listed in Section 8 Part I, Third Schedule to the Constitution of the Federal Republic of Nigeria, 1999. The powers include the preparation of an equitable formula for the distribution of all cadres of posts in the public service of the Federation and the states in Nigeria, the armed forces, the Nigerian Police Force as well as other government security agencies, government owned companies and parastatals of the states. The Commission is also mandated to ensure that every public company or corporation reflects the federal character in the appointment of its directors and senior management staff.
} 
is regarded as a "stranger" in the state of his birth and domicile on the grounds that his parenthood is of another state (Anugwom,2000; Adeosun, 2011 Ogunrotifa,2012). It is submitted that this position runs contrary to the fundamental human right principle of the right to freedom from discrimination. Article 2 of the Universal Declaration on Human Rights states that:

Everyone is entitled to all the rights and freedom set forth in this

Declaration, without distinction of any kind, such as race, color, sex, language, religion, political or other opinion, national or social origin; property, birth or status. Furthermore, no distinction shall be made on the basis of the political, jurisdictional or international status of the country or territory to which a person belongs whether it be independent, trust, non-self-governing or under any other limitation of sovereignty. ${ }^{3}$ (Orji, 2001)

This Article of the Declaration is the basis for Section 42 of the Constitution of Nigeria (1999) which states that:

A citizen of Nigeria of a particular community, ethnic group, place of origin or political opinion shall not by reason only that he is such a person be subjected either expressly by, or in the practical application of, any law in force in Nigeria or any executive or administrative action of the Government, to disabilities or restrictions to which citizens of Nigeria of other communities, ethnic groups, places of origin, sex, religious or political opinions are not made subject.

The section further provides that "no citizen of Nigeria shall be subjected to any disability or deprivation merely by reason of the circumstances of his birth" This provision, at this stage stands as an antidote to the quota principle as ethnicity does not play a role in the opportunities, privileges or advantages which a Nigerian citizen can benefit from. However, Subsection (3) of the same Section 42 unfortunately strengthens the quota principle and places ethnicity above merit by stipulating that:

Nothing in subsection (1) of this section shall invalidate any law by reason only that the law imposes restrictions with respect to the appointment of any person to any office under the State or as a member of the armed forces of the Federation or a member of the Nigeria Police Force or to an office in the service of a body corporate established directly by any law in force in Nigeria.

As a matter of fact, the Federal Character principle is not limited to the sections reproduced above. Rather, it is deeply entrenched in the Nigerian Constitution (1999). For example, Section 171 (5) of the Constitution (1999) mandates the President to have recourse to the Federal Character of Nigeria when appointing the Secretary to the Government of the Federation, the Head of the Civil Service of the Federation, Ambassadors, High Commissioners, Permanent Secretaries in any Ministry, or Heads of any Extra-Ministerial Department of the Government of the Federation and also any office on the personal staff of the President.

Furthermore, section 217 (3) of the same Constitution provides that "the composition of the officer corps and other ranks of the armed forces of the Federation shall reflect the Federal Character of Nigeria."

It is submitted that the Federal Character principle is ostensibly beneficial to the unity of Nigeria as it should ordinarily minimize apathy or disaffection from any ethnic group by ensuring that all groups are adequately represented in the national scheme of affairs. Unfortunately, many years of misrule and government insincerity, coupled with the extended concentration of federal powers in the hands of a particular ethnic group to the exclusion of others, has made a mockery of the Federal Character principle (Orji, 2001). Presently, Nigeria is widely recognised to be divided into six geopolitical zones as indicated in the aborted Draft Constitution of 1995 (Umeagbalasi, 2010; Ekwueme, 2012) but attempts to confer validity on the geo-political zones by their inclusion in the 1999 Constitution has been opposed in some quarters on the grounds that the northern zone is presumably larger than all other zones and as such, other zones should not be equated with the north (Odiegwu, M., Ubabukoh,O., Baiyewu.L \& Okpi,A.,2012). Furthermore, there are four main regional groupings along ethnic lines, namely the Northern group which comprises of three Northern geo political zones; the south-west group, the south-east group and the south-south group (PBS Newshour, 2007). It has been observed that throughout the post-colonial history of Nigeria, the different ethnic groupings have "pursued distinct ideologies and interests, and in the present dispensation, their agenda are still different"(Okpi, 2012). This fact belies the federal character of Nigeria (Odiegwu, M., Ubabukoh,O., Baiyewu.L \& Okpi,A.,2012; Ayim, 2012).

\section{Evolving a Strategy to Wipe out the Legacy of Colonialism}

Nigeria actually runs a pseudo-unitary system of government even though the system is seemingly a federal one. The socalled federating units or states in Nigeria rely on the Federal Government for sustenance as other viable avenues for

\footnotetext{
${ }^{3}$ Universal Declaration of Human Rights (Adopted 10 December 1948) Resolution 217 A(III). The Declaration is not directly binding on states but states have agreed that the Declaration constitutes an obligation for the members of the international community as decided at the Tehran Conference on Human Rights of 1968.
} 
income such as agriculture and mining of mineral deposits have been totally abandoned in favor of the oil wealth controlled by the Federal Government. As such, the consensus is that the discovery of crude oil in Nigeria has amounted to a curse rather than a blessing because, while oil revenues have increased over the years, Nigeria's economy has plummeted due to unrestrained embezzlement by government officials leading to an escalation of poverty and decay in infrastructure (Tamuno, 2006; Lloyd-Roberts, 2009; Iriekpen, 2012). In essence, the Federal Government remains the allpowerful source of sustenance while the federating states remain parasitic appendages (Akujobi \& Akujobi,2009; Awolowo,2011). This situation is worsened by the fact that most of the funds received from the Federal Government by the states are spent on recurrent expenditure with little or nothing left for capital projects that will benefit citizens (Gabriel, 2012). The wasteful spending pattern of the Nigerian government has continuously been a cause for concern (Okanlawon, 2012; Fuel Subsidy, 2012; Egunjobi,2013).

It is the over-reliance on the Federal Government that necessitates the continued application of Federal character in all spheres of the Nigerian polity. It is submitted that if the different ethnic groups look inward and harness their vast natural and human resources, the unabashed scramble for positions and hand-outs from the Federal Government will be greatly reduced.

Furthermore, the need for rapid socio-economic development of the various ethnic groups in Nigeria and the desire to partake of the largesse from the Federal Government accounts for why each ethnic group fights against marginalization by the Federal Government (Anugwom 2000; Oshelowo,2011) .To curb this trend, the solution lies in the Constitution. Chapter II of the Nigerian Constitution sets out the Fundamental Objectives and Directive Principles of State Policy for the Nigerian government. These objectives include the duty to ensure that suitable and adequate shelter, suitable and adequate food, reasonable national minimum wage, old age care and pensions, unemployment benefits and welfare of the disabled are well taken care of by the government. ${ }^{4}$ Other stipulated objectives of the government include that of controlling the national economy in such a manner as to secure the maximum welfare, freedom and happiness of every citizen on the basis of social justice and equality of status and opportunity; ensuring equal and adequate educational opportunities at all levels; as well as protection and preservation of the environment. ${ }^{5}$ If the Fundamental Objectives and Directive Principles of State Policy as contained in Chapter II of the Constitution are carried out by the Federal Government, the federating units of Nigeria will be better off and there will be no need to engage in continuous rivalry (Ogunniran, 2010). However, this is not the case in Nigeria as the rights set out in Chapter II of the Constitution are Socio-economic rights which the Constitution itself deems as non-justiciable rights and are thus unenforceable in court. ${ }^{6}$ Consequently, the government and political office holders cannot be held accountable in court for the wanton neglect inflicted on citizens whilst looting the treasury of public funds ('Nigeria: A chronicle',2012; Ogunmade,2013).

It is easy to ascribe Nigeria's present economic woes, ethnic rivalry and general instability to colonialism, however, the fact that Nigeria has so far failed to produce a truly nationalistic leader, even under a democratic dispensation coupled with the sheer magnitude of obscene corruption perpetrated by government officials has only emphasized the fact that failure of governance in post-colonial Nigeria rather than colonialism is the main reason for Nigeria's present predicament (Ogbeidi,2012; Chukwuemeka,Ugwuanyi \& Ewuim, 2012; Lawal,Imokhuede \& Johnson,2012; Lewis,2013). For example, if the Federal Government makes an attempt to control the national economy in such manner as to secure the maximum welfare, freedom and happiness of every citizen on the basis of social justice and equality of status and opportunity as directed by section 16 of the Nigerian Constitution, none of the ethnic groups will have a valid reason to complain of marginalization. Furthermore, if the Federal Government ensures that the economic system of Nigeria is not operated in such a manner as to permit the concentration of wealth or the means of production and exchange in the hands of few individuals or of a group as stipulated by the Constitution, there will be no basis to refer to colonialism as the origin of Nigeria's woes.

Also importantly, if the Federal Government strives to ensure that suitable and adequate shelter and food as well as equal and adequate educational opportunities at all levels are available to Nigerians, as a whole without regards to ethnicity, most of Nigeria's problems as a corporate entity will be solved. Unfortunately, rather than strive for national development, the ultimate quest in Nigeria is to secure control of oil resources of Nigeria which has invariably led to the categorization of Nigeria as a rentier state.

\footnotetext{
${ }^{4}$ Section 16(2)(d) Constitution of the Federal Republic of Nigeria, 1999.

${ }^{5}$ Section 20 Constitution of the Federal Republic of Nigeria, 1999

${ }^{6}$ Section 6(6) Constitution of the Federal Republic of Nigeria 1999. In Abacha v. Fawehinmi (2001) 6 NWLR (pt. 660) 228 the Supreme Court of Nigeria held that even though economic, social and cultural rights are contained in the African Charter on Human Rights which is now a part of Nigerian laws, such rights cannot be enforced because the Nigerian Constitution has declared such category of rights as non-justiciable.
} 


\section{Nigeria as a Rentier State}

A rentier state is defined as a country which receives substantial amounts of oil or other types of revenues from the outside world on a regular basis. Such country is independent from its society, unaccountable to its citizens and autocratic (US Legal, n.d.). A rentier state and rentier economy are said to contribute to a rentier mentality which adversely affects a country's economy and long-term prospects.

Adogahme (2011) identifies Nigeria as a classic rentier state where the rentier mentality is so pervasive that it has become ingrained in the consciousness of the populace such that oil revenue is seen as a "national cake" which every citizen clamours for and that the Federal Government of Nigeria is perceived as a revenue distributive organ of a rentier state. Nigeria's categorization as a rentier state is strongly supported by the fact that oil accounts for about $90 \%$ of Nigeria's exports and about 75\% of consolidated budgetary revenues (World Bank, 2013b). According to Beblawi (1990), rentier states tend to promote weak political and economic development while also creating a corrupt and irresponsible public sector rather than an efficient and responsive one. This is exactly the case in Nigeria and the situation is compounded by the fact that a rentier state like Nigeria which is heavily dependent on rentier income is vulnerable to the volatility of the world oil markets thereby reducing budgeting and long-term development plans into academic exercises. It is submitted that the rentier mentality afflicting the government and citizenry in Nigeria is responsible for the negligent collapse of the oil refineries in Nigeria to the extent that Nigeria exports crude oil and imports refined petroleum at a greater expense whilst allegedly subsidizing the price of petrol for the Nigerian consumers (Soriwei,2012; Obeche, n.d.). Accordingly, Omeje (2006) argues that oil presents a horrendous paradox to Nigeria by providing enormous wealth and means of patronage to the rentier state and its joint venture partners, that is, the transnational oil companies while serving as a source of anxiety and misery to the local oil producing communities. This raises the notion of state capture where Nigeria's economy and livelihood is held hostage to the will of multinational oil companies whose position is strengthened by Nigeria's lack of requisite technology to exploit her oil resources. Hence, Nigeria which is excruciatingly dependent on oil must invariably rely on foreign multinational companies to exploit the oil according to the pleasure of the multinational companies (Ebohon, 2013). As such, Nwankwo(1985) suggests that in as much as the ultimate test of a good government is the welfare of the people, no nation can provide for the welfare of its citizens as long its economy is fettered. He posits that there is a need to cut off the pervasive tentacles of multinational companies for Nigeria to survive. Dankofa(2008) on his own part ascribes Nigeria's rentier state problems to colonialism, ethnic conflagrations and the parasitism of the ruling class.

It must be noted however, that the legacy of colonialism in Nigeria transcends the problem of ethnicity. Colonialism has an indelible imprint on the Nigerian Legal System which needs to be reviewed.

\section{The Influence of Colonialism on Nigeria's Legal System}

The influence of colonialism on Nigeria's legal system is indeed very profound as British law presently constitutes one of the major sources of Nigerian law. As such, the common law of England, the doctrines of equity and the Statutes of General Application in force in England as at January 1, 1900 are still valid laws in Nigeria (Malemi, 1999). This is evident in the High Court Laws and High Court Civil Procedure Rules of States in Nigeria. The subservience of Nigeria's legal system to colonial laws especially judicial decisions is expounded by Agbede(1989,p.18) to the effect that:

The explanation appears to be that prior to the attainment of independence, the majority of the personnel of the Nigerian superior courts were English. Moreover, the Nigerian judges themselves are trained in English Law. It is only natural that they should be fascinated by the decisions of the English superior courts, which in any case, are in line with their own reasoning.

It is however heartening to know that even though resort to English law still forms part of Nigeria's laws, Nigerian Courts have established the stance that English judicial authorities are merely of persuasive value in Nigerian courts as opposed to the previous situation where such decisions made in England are binding on Nigerian courts. The present position adopted by Nigerian Courts is explicitly rationalized by Tobi (2007) thus:

It is therefore worrying, to say the least, for a sovereign nation, to continue to make use of laws of a foreign Country with the same sovereign status, in search of justice in a jurisprudence which is supposed to be indigenous to its peoples. It is much more worrying when the application of elements of foreign laws is forced up that sovereign nation by so-called enabling statutes. The million naira question is: Why should the legal system of this Country continue, as a matter of law, to operate English Statutes, some of which have either been repealed or gone through several amendments? Why should Nigeria continue to operate such English statutes that are of little or no relevance to our sociology and anthropology? 
Even though, the Nigerian Judiciary has detached itself from the apron-strings of colonial judicial authority, the Nigerian Legislature has fared worse as certain statutes introduced by the British into Nigeria are still in force even though the provisions of the said statutes are of the diminished value or have become irrelevant in contemporary times. In the words of Esiemokhai (2012) :

Unlike India which has moved away from the British legal system and had established a social justice system, which has visibly propelled India to gain acceleration in the right direction, a Nigerian jurisprudence has not yet emerged. The Nigerian Constitution contains social justice principles but these social justice proclamations are not justiciable but are hortatory in nature.

An example that readily comes to mind is section 34 of the Nigerian Criminal Code which provides that a husband and wife of Christian marriage are not criminally responsible for a conspiracy between themselves alone. This provision is a colonial legacy which reflects British recognition of Christian marriage as the only valid form of marriage to the exclusion of other forms of marriage which exist in Nigeria (Adesanya, 2009). Furthermore, section 162 of the Nigerian Evidence Act pertaining to Competence and Compellability of witnesses is to the effect that a spouse of a Christian marriage is not a competent and compellable witness against his or her spouse upon any criminal prosecution. This provision also excludes Nigerians who are married under Native Nigerian Law or custom and is highly discriminatory (Kolawole, 2009).

In spite of the above, it will amount to abdication of responsibility if deficiencies in Nigerian Statutes are laid at the doorstep of colonialism. The Nigerian Legislature as well as the Nigerian Law Reform Commission must of a necessity awake from legislative inertia and repeal colonial laws in favor of laws which reflect Nigeria's contemporary socio-political milieu. Tobi (2007) aptly conveys this message thus:

If the colonialists, in their usual sensitivities characteristic of exploration and discovery, exported their laws to the colonies, the colonized on their attainment of independence should be able to jettison the colonial system in all its ramifications and adopt its own system. This is the function of the Legislature.

It is worthy of note that relics of colonialism also abound in the practice of Law in Nigeria. For instance, Lawyers in Nigeria cannot appear in Court without wearing the traditional wig and gown as proffered by the British. Although the wig and gown distinguishes members of the learned profession, it becomes a burden especially when the weather is hot and where the Court rooms are not well ventilated as is usually the case. Apart from the argument that the legal profession has a conservative tradition which must not be tampered with, it can also be argued that the wig and gown does not have any bearing on quality delivery of legal service or whether it improves advocacy in court.

Another cause of controversy is the appointment of Senior Advocates of Nigeria adopted in line with the Queen's Counsel model operating in Britain. Although the rank of Senior Advocate is the zenith of the legal profession in Nigeria, there are increasing calls for its abolition on the grounds that it is a colonial legacy which creates a supposedly superior class of lawyers who receive preferential treatment in all spheres of legal practice to the detriment of other members of the legal profession (Adesomoju, 2013). This is another controversy traceable to colonialism which is a divisive factor in the legal profession and is in need of urgent review.

\section{Conclusion}

This paper set out to identify the major problem confronting Nigeria's corporate existence as a sovereign nation which is the problem of ethnicity and ethno-religious conflict as well as the underlying cause of the socio-economic privations suffered by a large number of Nigerian citizens. The problem of ethnicity is widely attributed to the effects of colonialism many decades after Nigeria attained independence. Colonialism is not without its ills and these include the the institutionalization of ethnic rivalry and distrust in the wake of the forced amalgamation of the diverse ethnic groupings which now make up Nigeria. The intense ethno-religious conflict which has claimed many innocent lives has led to doomsday prophesies of Nigeria becoming a failed state in the near future. Nigeria has survived a bloody civil war caused by an ethnic pogrom perpetrated in Northern Nigeria which led to secessionist attempts by the Ibos of South-East Nigeria, one of the major ethnic groups in Nigeria. Nigeria is still one country but the unity remains fragile as ethno-religious conflicts persist. However, the present ethnic unrest in Nigeria cannot be totally blamed on the British as Nigeria has had ample time, opportunities as well as the requisite resources to erase the scars of colonialism. As such Akinyele asserts that the fundamental problem of Nigeria is not ethnicity or religion but their politicization coupled with the manipulation of impoverished citizens by the elite who play upon ethnic and religious sentiments to fulfill selfish goals (Akinyele, 2003).

Another major problem besetting Nigeria is the massive corruption perpetrated by the political elites and the ruling class in conjunction with foreign oil companies such that Nigeria is categorized as a rentier state on the verge of becoming a failed state. This phenomenon is attributed to the discovery of oil and the attendant oil curse which is 
responsible for aggravating the ethnic tensions entrenched by colonialism as every ethnic section of Nigeria strives to get the largest allocation from the oil revenue.

It is submitted that if the Government of Nigeria can tackle corruption with sincerity of purpose and embark on appropriate developmental projects which will improve the quality of life of the millions of deprived Nigerians, there will be less protests of marginalization from different ethnic groups and there will be less ethnic intolerance. There will be less controversy or discontent about the Federal character principle or the quota system.

The purpose justice will not be served with reliance on archaic laws, especially laws which were drafted by colonial overlords. Laws made by colonial masters for colonial subjects should have no place in a democratic sovereign state. Hence, it is submitted that Statutes preceding Nigerian independence which are still operational need to be urgently revised or abolished as the need arises.

This paper seeks to establish that notwithstanding colonialism, the divergent ethnic groups and varying interests, Nigeria need not degenerate into a failed state. Thus, if the suggestions made are duly implemented, Nigeria as a unified entity will be the better for it.

\section{References}

Abdulrahman, D. (2004). Colonialism, development paths, globalization and social inequality: The sources of social conflict in Nigeria. In D. Oni, S.Gupta,T.Omoniyi,E.Adegbija \& S.Awonusi (Eds.), Nigeria and Globalization: Discourses on Identity Politics and Social Conflict (pp.291-326).Lagos: CBAAC.

Adebisi, M.A. (1998).Ethnic relations and politics in Nigeria.In U.A. Igun \& A.A. Mordi (Eds.) Contemporary Social Problems in Nigeria. (20-38)Illorin: Department of Sociology, UNILORIN

Adefulu, R. (2001).The context of politics and governance in postcolonial Nigeria. In R. Adefulu \& W. Olaitan (Eds.), Issues in Nigerian government and politics (pp. 8-24) ljebu-Ode: RAD Consultancy.

Adeosun,A.B. (2011).Federal character principle and national integration: A critical appraisal. International Journal of Politics and Good Governance, 2(2), 1-13.

Adesanya, B. (2009, June 12).Marriage, divorce and succession: The legal aspects. Retrieved from <www.dioceseoflagoswest.org/ Pastorallssues/Teachings/MARRIAGE,\%20DIVORCE\%20AND\%20SUCCESSION\%20-\%20THE\%20LEGAL\%20ASPECTS.htm

Adesomoju, A. (2013,July 22). New SANs emerge amid calls for reform. Punch. Retrieved from www.punchng.com/feature/the-lawyou/new-sans-emerge-amid-calls-for-reform/

Adogahme, P.G.(2011).Reforming the rentier state: The challenges of governance reforms in Nigeria. Journal of Energy and Development, 34(2), 227-252

Afonja, B.(2013,November 13).Nigeria: A nation in dilemma. The Guardian. Retrieved from www.ngrguardiannews.com/ index.php/features/policy-a-politics/138347-nigeria-a-nation-in-dilemma

Agbede, I.O.(1989) Themes on conflict of laws .Lagos: Shaneson

Akinyele, R.T. (2003). Ethnicity, religion and politics in Nigeria. In R. A. Olaniyan (ed.) The Amalgamation and its enemies: An interpretive history of modern Nigeria. (pp.123-148) Ile-lfe :OAU Press.

Ako-Nai, R.I. (2004). The politics of marginalization in Nigeria: Challenges of the fourth republic. In D. Oni, S.Gupta,T.Omoniyi,E.Adegbija \& S.Awonusi (Eds.), Nigeria and Globalization: Discourses on Identity Politics and Social Conflict (371-387).Lagos: CBAAC.

Akujuobi, L.E. \& Akujobi A.B.C. (2009). Financing state governments in Nigeria: 1980-2007. African Research Review ,3(3), 204-215.

Aleyomi, M.B. (2012).Ethno-religious crisis as a threat to the stability of Nigeria's federalism. Journal of Sustainable Development in Africa, 14(3), 127-140.

Anugwom,E.E.(2000). Ethnic conflict and democracy in Nigeria: The marginalisation question. Journal of Social Development in Africa, 15(1), 61-78.

Apata, Z.O. (1990).Lugard and the creation of provincial administration in northern Nigeria 1900-1918. African Study Monographs ,11(3), 143-152.

Awolowo, D. (2011).Fiscal federalism in Nigeria: Theory and dimensions. Afro-Asian Journal of Social Sciences, 2(2.2), 1-21.

Ayim, U. (n.d.).'Much ado about geo-political zones and governors forum? Retrieved 27 August, 2014 from http://omojuwa.com/2012/08/much-ado-about-geo-political-zones-and-governors-forums/

Azeez, A. (2004). The dynamics of ethnic politics and democratic consolidation in Nigeria: A prognosis. In D. Oni, S.Gupta,T.Omoniyi,E.Adegbija \& S.Awonusi (Eds.), Nigeria and Globalization: Discourses on Identity Politics and Social Conflict (327-342).Lagos: CBAAC.

Azeez, A. (2009).Ethnicity, party politics and democracy in Nigeria: Peoples Democratic Party (PDP) as agent of consolidation? Stud Tribes Tribals, 7(1), 1-9.

Beblawi, $\mathrm{H}(1990)$.The rentier state in the Arab world. In G. Luciani (ed.) The Arab State (pp.85-98) London: Routledge

Black's Law Dictionary (9th ed.).(2009). St.Paul, MN: West Publishing Co.

Bunce,V.J.(n.d.).The violent dissolution of Yugoslavia: A comparative perspective. Wilson Center. Retrieved 28 August 2014 from http://www.wilsoncenter.org/publication/141-the-violent-dissolution-yugoslavia-comparative-perspective 
Chukwuemeka, E., Ugwuanyi,B. and Ewuim,N. (2012).Curbing corruption in Nigeria: The imperatives of good leadership. African Research Review ,6(3), 338-358.

Constitution (1999). Federal Republic of Nigeria

Dankofa, Y. (2008). The fallacy of democracy in the absence of development and rule of law: The need for the enthronement of constitutional democracy in Nigeria. ABU Journal of Public and International Law, 1(2), 158.

Eames, E.A. (1985, Fall). Party politics and ethnic identity in Nigeria 1979-1983. Cultural Survival. Retrieved from www.culturalsurvival. org/publications/cultural-survival-qarterly/nigeria/regional-rivalry-party-politics-and -ethnic-identity

Ebohon, S.I. (2013) State and rentier capitalism in Nigeria: The political economy of hydrocarbon nationalism and dependence reproduction. Journal of Third World Studies, 30(1),209-236.

Egunjobi, T.A. (2013).Re- engineering public expenditure patterns for economic development in Nigeria. Management Science and Engineering, 7(2), 28-40.

Ekwueme, A. (2012, October 29). What Nigeria lost by Abacha's untimely death. The Source. Retrieved from http://www. thesourceng.com/DeathOctober292012.htm

Engelberg, S.(1993,January 1).Czechoslovakia breaks in two, to wide regret. New York Times. Retrieved from http://www.nytimes. com/1993/01/01/world/czechoslovakia-breaks-in-two-to-wide-regret.html?pagewanted=all\&src=pm

Ensign, M. (2012, January 1).Religious tolerance in Nigeria: A view from the north. Huffington Post. Retrieved from http://www.huffingtonpost.com/margee-ensign/religious-tolerance-in-ni b 1235764.html

Erhagbe, E. (2012).Ethnicity in the matrix of peace and reconciliation in Nigeria. European Scientific Journal, 8(16), 82-94.

Esiemokhai, E.O. (2012, March 27).The failure of the colonial legal system in Nigeria: A rhapsodic passacaglia on a legal theme. Focus Nigeria. Retrieved from www.focusnigeria.com/Colonial-Legal-System.htm

Eteng,I.A. (2004).Ethnicity, ethno-class relations and crisis of Nigeria's enduring ' national question' and political instability' in In D. Oni, S.Gupta,T.Omoniyi,E.Adegbija \& S.Awonusi (Eds.), Nigeria and Globalization: Discourses on Identity Politics and Social Conflict (37-81).Lagos: CBAAC.

Ethnicity in Nigeria. (2007, April 5). PBS Newshour. Retrieved from http://www.pbs.org/newshour/updates/africa/jan-june07/ethnic_0405.html

Federal Character Commission. Retrieved 26 August, 2014 from http://federalcharacter.gov.ng/establishment.php

Felix Tamuno, J.M. (2006).Crude oil resource: A blessing or curse to Nigeria- The case of the Niger-Delta. Journal of Research in National Development, 4(2), 53-58.

Fuel subsidy and waste in budgeting. (2012, January 5) Punch. Retrieved from http://www.punchng.com/editorial/fuel-subsidy-andwaste-in-budgeting/

Gabriel, O.(2012, March 12).Revised 2012-2014 revenue/expenditure framework: Tough and harder times ahead. Vanguard. Retrieved from http://www.vanguardngr.com/2012/03/revised-2012-2014-revenue-expenditure-framework-tough-and-harder-times-ahead/

Gerhart, G.M.(1997). F.D Lugard's The dual mandate in British tropical Africa. Foreign Affairs, September/ October 1997. Retrieved from http://m.foreignaffairs.com/articles/53371/gail-m-gerhart/the-dual-mandate-in-british-tropical-africa

Iriekpen, D. (2012, April 30). The trouble with crude oil. Thisday Live. Retrieved from http://www.thisdaylive.com/articles/the-trouble-withcrude-oil/114838/

Iwara,A.U. (2004).Identity politics, globalization and socio-political engineering in Nigeria. In D.

Oni, S.Gupta,T.Omoniyi,E.Adegbija \& S.Awonusi (Eds.), Nigeria and Globalization: Discourses on Identity Politics and Social Conflict (19-36).Lagos: CBAAC.

Kolawole, A.K.A. (2009).Validity of 'double-deck' marriages in Nigeria. Olabisi Onabanjo University Law Journal, 1(1), 1

Kwarteng, K. (2012, March 29). Nigeria's current troubles and its British colonial roots. The Globalist. Retrieved from http://www. theglobalist.com/nigerias-current-troubles-and-its-british-colonial-roots/

Lalude, G. \& Omitola, B. (2001) British colonial policy in Nigeria, in R. Adefulu \& W. Olaitan (Eds.), Issues in Nigerian government and politics.( pp.25-39) RAD Consultancy

Lawal, T., Imokhuede, K. \& Johnson, I. (2012). Governance crisis and the crisis of leadership in Nigeria. International Journal of Academic Research in Business and Social Sciences 2(7) 185-191

Lewis, P.M.,(n.d.).The dysfunctional state of Nigeria. Center for Global Development. Retrieved from http://www. cgdev.org/doc/shortofthegoal/chap3.pdf > accessed 21 November 2013

Lloyd-Roberts, S. (2009, January 3).The curse of Nigerian oil. BBC News. Retrieved from http://news.bbc.co.uk/2/hi/programmes/ from_our_own_correspondent/7808670.stm

Malemi, E. (1999). The Nigeria legal system: Text and cases. Lagos: Princeton

Nigeria: A Chronicle of thieving leaders. (2012, April 22) The Street Journal. Retrieved from http://thestreetjournal.org/2012/04/nigeria-achronicle-of-thieving-leaders/

Nnochiri,I. \& Offide,E. (2012, November 6). State of origin: Female judge denied appeal court seat. The Vanguard. Retrieved from http://www.vanguardngr.com/2012/11/state-of-origin-female-judge-denied-appeal-court-seat/

Nwakwo, A.A. (1981). Can Nigeria survive? Enugu: Fourth Dimension Publishers.

Obeche, O. (n.d).Oil subsidy: Beyond the figures. The Economy. Retrieved 21 November 2013 from http://www.theeconomyng. com/news101.html

Odiegwu, M., Ubabukoh,O., Baiyewu.L \& Okpi,A. (2012, August 12).Constitution: Six geopolitical zones divide north, south. Punch. Retrieved from www.punchng.com/news/constitution-six-geopolitical-zones-divide-north-south 
Ogbeidi, M. (2012). Political leadership and corruption in Nigeria since 1960: A socio-economic analysis. Journal of Nigeria Studies, 1(2), $1-25$.

Ogunmade, O. (2013, June 19). $\$ 600$ billion stolen by Nigerian elite since independence. Thisday Live. Retrieved from http://www.thisdaylive.com/articles/-600bn-stolen-by-nigerian-elite-since-independence/150863/

Ogunniran, I. (2010). Enforceability of socio-economic rights: Seeing Nigeria through the eyes of other jurisdictions. UNIZIK JILJ ,1(1)7387.

Ogunrotifa, A.B. (2012).Federal civil service reform in Nigeria: The case of democratic centralism. Radix International Journal of Research in Social Science, 1(10), 1-46.

Okanlawon, S. (2012, March 25).Who is afraid of regional integration? Punch. Retrieved from http://www.punchng.com/opinion/who-isafraid-of-regional-integration/

Okoye,J.C., Egboh, E.A.\& Chukwuemeka, E.O.(2012).Changing Perspectives of Nigeria Political Development: From Militarism to Incumbency and Godfatherism. Journal of Political Studies, 19(1) 1-17.

Okpi, A. (2012, March 25). Nigeria's regions and their increasing agenda. Punch. Retrieved from_http://www.punchng.com/ politics/nigerias-regions-and-their-increasing-agenda/

Olaniyan, R \& Alao, A. (2003). The amalgamation, colonial politics and nationalism, 1914-1960. In R.A. Olaniyan (Ed.) The Amalgamation and its Enemies: An interpretive history of modern Nigeria (1-22). lle-Ife: Obafemi Awolowo University Press.

Omeje, K. (2006). The rentier state: Oil-related legislation and conflict in the Niger-Delta, Nigeria. Conflict, Security and Development, $6(2), 211-230$.

Onasode, G. (1993). Three decades of development crises in Nigeria. Lagos :Malthouse Press.

Orji, E.I. (2001). Issues on ethnicity and governance in Nigeria: A universal human rights perspective. Fordham International Law Journal 25(2) 431-482.

Oshewolo, S. (2011). Politics of integration and marginalisation in a federation: The south-south question in Nigerian politics. International Journal of Politics and Good Governance, 2(2.1), 1-15.

Oyeniya,R.K. (2011, August 1). The truth Nigerians must not know - Part 2: Over-bloated government. Sahara Reporters. Retrieved from http://saharareporters.com/article/truth-nigerians-must-not-know-\%E2\%80\%93-part-2-over-bloated-government

Ploch, L. 'Nigeria: Current Issues and U.S. Policy' (Congressional Research Service, 24 April 2013). Retrieved from http://www.fas.org/sgp/crs/row/RL33964.pdf

Soriwei, F.(2012, July 7).Two of Nigeria's refineries pack up...Others produce at $25 \%$ of installed capacity. Punch. Retrieved from http://www.punchng.com/news/two-of-nigerias-refineries-pack-up-others-produce-at-25-of-installed-capacity/

The World Fact Book.(n.d). Retrieved August 27, 2014 from https://www.cia.gov/library/publications/the-world-factbook/geos/ni.html

Tobi, N. (2007) Sources of Nigerian law. Lagos:MIJ

Uduchukwu, C. (2013, June 12).The sins of Nigerian federal character principle. Daily Post. Retrieved from http://dailypost.com.ng/2013/06/12/chukwumerie-uuchukwu-the-sins-of-nigerian-federal-character-principle/

Uhunmwuangho, S.\& Epelle, A. (2011) Challenges and solutions to ethno-religious conflicts in Nigeria: Case study of Jos crises. Journal of Sustainable Development in Africa, 13(5), 109-124.

Umeagbalasi, E. (2010, October 14). Nigeria's national assembly at 50: Time for stocktaking. Vanguard . Retrieved from http://www.vanguardngr.com/2010/10/nigeria\%E2\%80\%99s-national-assembly-at-50-it-is-time-for-stock-taking/

Universal Declaration of Human Rights (1948).

US Legal. (n.d). Rentier state law and legal definition. Retrieved August 25, 2014, from http://definitions.uslegal.com/r/rentier-state/

Vincent, C. (2009, June 2).Demerits of the quota system. The Nation. Retrieved from http://thenationonlineng.net/web2/article/ 53201/Demerits-of-the-quota-system/page1.html

Wills, A.J. (1966). African politics in Central Africa. In J.C. Anene \& G. Brown (Eds.), Africa in the Nineteenth and Twentieth Centuries (504-527) Ibadan: University Press.

World Bank. (May 2013b) Nigeria Economic Report (No.1). Retrieved from: <www.wds.worldbank.org/external/default/WDS ContentServer/WDSP/IB/2013/05/14/000333037_20130514101211/Rendered/PDF/776840WPONigerOBox0342041B00PUBLIC0 .pdf $>$

World Bank. (2013a).Nigeria Overview. Retrieved from the World Bank website. http://www.worldbank.org/en/country/nigeria/overview 